\title{
A LYCOPODIACEOUS STROBILLS FROM THE POCONO SANDSTONE OF PENNSYLVANIA
}

\author{
Chester A. Arnold \\ (Received for publication May 17, 1932)
}

\begin{abstract}
Although several instances are known of the occurrence of lycopodiaceous fossils in the pre-Coal Measures rocks of North America evidences of their fructifications are exceedingly rare. For this reason a specimen recently found in the Pocono sandstone and which shows some of its internal organization is of considerable interest.

This specimen, along with several other plant fossils, was discovered during the summer of $I 93 \mathrm{I}$ in a small quarry about one and one half miles northeast of Port Allegany, McKean County, Pennsylvania. After they were collected these fossils had come into the possession of Mr. J. C. Galloway of Port Allegany, who, appreciating their possible scientific value, very kindly submitted them to the present author for study. Unfortunately the strobilus had undergone no petrifaction, with the consequence that many of the outstanding features of its internal organization were lost or hopelessly obscured. On the other hand certain structural features are preserved in a remarkable fashion.
\end{abstract}

The strobilus, as shown in text figure I, measures one and three-eighths by four inches. The sides are nearly parallel and the apex is bluntly rounded. Attached to it is a stout peduncle, about three inches long but incomplete, which appears to have had a pith. Whether or not this peduncle bore bracts cannot be determined, but the straightness of it suggests that the strobilus was originally borne in an upright position.

The upper half of the strobilus had undergone very little decay and the partial obliteration of the structure was caused rather by the severe flattening to which the strobilus had been subjected. A lengthwise split through this upper portion had exposed the axis (as shown in text fig. I) and by carefully removing some of the attached sporophylls with a small chisel the sporangia could be removed. These sporangia are radially elongated and still retain their spores, but whether they are attached to the upper surfaces of the sporophylls by their full lengths as is characteristic of some lycopods or whether they are attached distally to specialized sporangiophores as in the Calamariae or in Cheirostrobus or distally to the sporophyll as in Spencerites, could not be determined. It is assumed, however, that the former situation existed since there is considerable evidence that the strobilus is lycopodiaceous and belongs to the Sigillariae.

The sporophylls are a little more than half an inch long and are borne at right angles to the axis. They are in whorls about three-sixteenths of an inch 
apart and those in adjacent whorls alternate with each other. The exact number of sporophylls per whorl is indeterminable because of the distortion brought about by flattening, but they appear to have been numerous, probably twelve to twenty. This whorled arrangement of the sporophylls could be seen especially well where portions of the outer surface had been flattened against the enclosing sandstone. Also, at certain places along the exposed axis, the alternation could be seen.
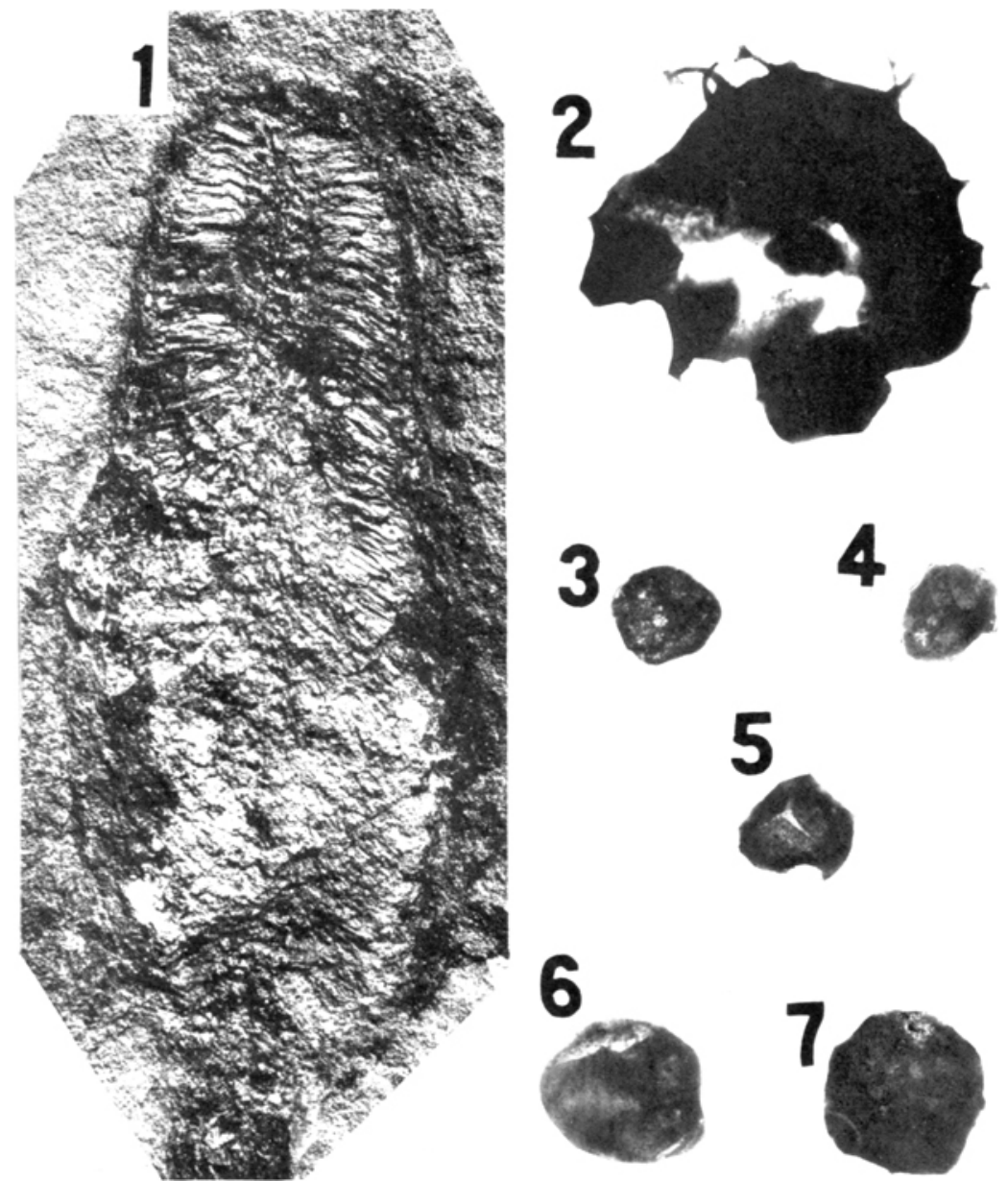

Text Figs. I-7. Fig. I. Photograph of strobilus, natural size. The axis is exposed in the upper part. FIG. 2. Portion of megaspore showing appendages. Diameter $\mathrm{I}^{2}$ microns. FIGs. 3, 4, 5. Microspores of the smaller type. Figure 5 shows the triradiate markings. Diameter about 38 microns. FIGs. 6, 7. Larger microspores. Diameter about 76 microns.

The presence of spores of different sizes in the sporangia indicates heterospory. The microspores vary considerably in size. The smaller and 
more numerous are around thirty-five microns (text figs. $3^{-5}$ ) but some of them are more than twice as large (text f:gs. 6-7). Nothing remains of any of the spores except the heavily cutinized coats. The triradiate markings showing where the four cells were originally joined together in the tetrad s.age are visible on some (text fig. 5). The microspore walls appear to have been slightly rough but there is no evidence of their having had long appendages.

The megaspores are much larger and less numerous. None of them were found complete and the process of pulverizing the carbonized sporangia for mounting was exceedingly destructive to the appendages. Judging from what could be seen of the megaspores their diameter is two or three times that of the largest microspores, or approximately one hundred and fifty microns or more (text fig. 2).

The shape and position of the sporangia and the sporophylls indicate lycopodiaceous affinities rather than equisetaceous affinities for this fossil. Whether or not it is a true Sigillaria is at present undecided. According to Zeiller. (4) the verticillate arrangement of the sporophylls in Sigillariostrobus is characteristic for the genus and serves as a means of distinguishing it from Lepidostrobus. He does attribute this feature to one species of Lepidostrobus of which, however, he expresses some doubts concerning its generic affinity.

Considerable interest centers about the exact geological age of the Pocono fossils. The Pocono sandstone is generally assumed to be the basal member of the Mississippian in northern Pennsylvania; but quite recently Chadwick (I), after making detailed studies of the lower Mississippian and Upper Devonian in that region and in southern New York, believes that the Pocono properly belongs to the Upper Devonian, thus placing the DevonioCarboniferous boundary above that formation rather than below it as has been done heretofore.

The possibility of the Pocono belonging to the Upper Devonian is supported to a certain extent by the occurrence along with the lycopod strobilus of a species of Archaeopteris closely resembling specimens of $A$. Roemeriana Goepp. from the Upper Devonian of Bear Island. Archaeopteris occurs only in Upper Devonian rocks, as far as it is known, and is sometimes used as an index fossil in assigning formations to that age.

Three new sigillarian genera, Helenia, Heleniella, and Amadokia, recently described by Zalesskij (3) from the Upper Devonian rocks of the Donetz Basin of south Russia, are of some interest in connection with the Pocono material. To Helenia, Zalesskij would assign the well-known specimen of Archaeosigillaria primaeva (Rogers) White from the Portage formation of New York (2). He recognizes a similarity between this and some of his newly discovered Russian material which, however, differs from the material upon which the original description of Archaeosigillaria was based. This possible similarity of the Russian and American material is of some signifi- 
cance in indicating a similarity of the flora between these two widely separated areas during Upper Devonian times. Also the Russian material lends strength to the sigillarian interpretation of the Pocono strobilus as well as to the probable Devonian age of the Pocono by indicating that the remains of the Sigillariae can be expected to occur in Devonian rocks.

\section{SUMMARY}

The specimen here described is an unpetrified lycopodiaceous strobilus from the Pocono sandstone near Port Allegany, McKean County, Pennsylvania, which is possibly of Upper Devonian age. The whorled arrangement of the sporophylls suggests sigillarian affinities. Both megaspores and microspores are present; the former measure approximately I 50 microns while the latter are smaller but quite variable in size. The recent discovery of sigillarian remains in the Upper Devonian of the Donetz Basin is a coincidence of some probable significance in connection with this.

Museum of Palaeontology, UNiversity OF MiCHigaN

\section{LITERATURE CITED}

I. Chadwick, G. H. The Pocono problem. Abstracts of the Paleontological Society. Preliminary list of titles and abstracts to be offered at the 44th Annual Meeting of the Geological Society of America, p. 6r. Tulsa. I93I.

2. White, D. A remarkable fossil tree trunk from the Middle Devonic of New York. New York State Mus. Bull. 107: 327-340. 1907.

3. Zalesskij, M. (Zalessky, M.). Végétaux nouveau du Dévonien superieur du bassin du Donetz. Bull. Acad. Sci. U. S. S. R. 557-588. I93I.

4. Zeiller, R. Flore fossile du bassin houiller de Valenciennes. Études des gites minéraux de la France. Texte et atlas. Paris, I886, I 888. 